\title{
APLIKASI PEMERIKSAAN BIAYA INSTALASI TEGANGAN LISTRIK RENDAH BERBASIS WEB PADA PT. PPILN MALUKU UTARA
}

\section{APPLICATION OF WEB-BASED ELECTRIC VOLTAGE INSTALLATION EXAMINATION COSTS IN.PT PPILN NORTH MALUKU}

\author{
Try Handayani ${ }^{1}$, Yayu Sumiyati Bin Taher ${ }^{2}$, Alfanugrah Hi Usman ${ }^{3}$, Arisandy Ambarita ${ }^{4}$ \\ ${ }^{1,2}$ Program Studi Komputerisasi Akuntansi, ${ }^{3}$ Program Studi Teknik Komputer \\ ${ }^{4}$ Program Studi Manajemen Informatika \\ Politeknik Sains dan Teknologi Wiratama Maluku Utara \\ yayubintaher@yahoo.co.id
}

\begin{abstract}
Abstrak
Penelitian ini dilakukan pada kantor PT. PPILN Maluku Utara bertujuan untuk membuat Aplikasi Pemeriksaan Biaya Instalasi Tegangan Listrik Rendah Berbasis Web Pada PT. PPILN Maluku Utara. Pengumpulan data melalui Wawancara, Observasi dan Studi literatur, Metode Analisys system menggunakan Model Driven secara terstruktur dengan model rancangan secara Bottom-Up. tools yang digunakan sebagai alat bantu rancangan adalah Flowchart, DFD, ERD, Sistem ini dijalankan pada Web server Xampp dengan bahasa pemrograman HTML, PHP, CSS, Javascript dan MySQL sebagai Databasenya. dalam pengujian sistem menggunakan model uji Blackbox. Dari hasil Implementasi dan Pengujian Sistem, Aplikasi Pemeriksaan Biaya Instalasi Tegangan Listrik Rendah Berbasis Web Pada PT. PPILN Maluku Utara dapat mempermudah karyawan dalam mengelola data rekapan laporan pemeriksaan biaya instalasi tegangan listrik rendah secara cepat, serta mempermudah pimpinan untuk dapat mengontrol laporan rekapan pemeriksaan biaya instalasi tegangan listrik rendah pada sistem dimana saja.
\end{abstract}

Kata kunci: Aplikasi, Pengolahan Data, Biaya Instalasi Tegangan Listrik, Website

\begin{abstract}
This research was conducted at the office of PT. PPILN North Maluku aims to make an Application to Inspect the Cost of Web-based Low Voltage Electrical Installation at PT. PPILN North Maluku. Data collection through Interviews, Observations and Literature Studies, Analysis System methods using a Model Driven structured with a design model in Bottom-Up. the tools used as design tools are Flowchart, DFD, ERD, this system is run on Xampp Web server with HTML, PHP, CSS, Javascript, and MySQL programming languages as its database. in testing the system using the Blackbox test model. From the results of System Implementation and Testing, Application for Inspection of the Cost of Web-Based Low Voltage Installation at PT. PPILN North Maluku can make it easier for employees to manage recapitulation data on inspection reports of low voltage installations. and make it easier for leaders to be able to control recapitulation reports checking the cost of installing low voltage on the system anywhere.
\end{abstract}

Keyword: Application, Data processing, Electricity Installation Fee, Website 


\section{PENDAHULUAN}

Dengan berkembangnya teknologi informasi maka disetiap perusahaan, instansi maupun organisasi melakukan migrasi ke penggunaan teknologi informasi sebagi penunjang dalam membantu dalam pelayanan maupun pekerjaan salah satu dengan memanfaatkan perangkat lunak atau aplikasi. Menurut Sukamto, et.al (2014:2), "Perangkat lunak (Software) adalah program computer yang terasosiasi dengan dokumentasi perangkat lunak seperti dokumentasi kebutuhan, model desain, dan cara penggunaan (user manual).

Penilitian sebelumnya yang dilakukan oleh yuanita dan Sukadi dengan judul "Sistem Informasi Administrasi Pembayaran Iuran Bulanan (SPP) Dan Dana Sumbangan Pendidikan (DSP) Siswa Taman Kanak-Kanak Negeri Pembina Kecamatan Pringkuku" mengatakan bahwa Pada dasarnya pengolahan data keuangan siswa serta pencarian data membutuhkan waktu yang lama karena harus mencari dan mencocokan arsip-arsip. Untuk itu, perlu suatu sistem yang terintegrasi dengan pemakaian teknologi komputer guna mencapai dan mempercepat proses pemasukan data dan pelaporan.

PT. PPILN (Perintis Perlindungan Instalansi Listrik Nasional) WILAYAH MALUKU UTARA Merupakan perusahaan swasta yang beralamatkan di Jln. Cempaka No. 173. Tanah Tinggi, Ternate Selatan Kota Ternate. Perusahaan tersebut bergerak dibidang jasa pemeriksaan instalasi listrik tegangan rendah milik konsumen.

Dalam mengelola data laporan biaya pemeriksaan masih menggunakan alat bantu Aplikasi Microsoft Excel, pada data rekapan laporan berada pada setiap sheet yang harus di dihitung secara satu per satu dengan memasukan rumus secara manual, sehingga potensi kesalahan dalam penjumlahan dapat terjadi, disamping itu harus membuka satu per satu laporan pada setiap sheet sehingga dianggap lambat dan kurang efisien, dan dibutuhkan satu sistem yang dapat membantu dalam mengelola data pemeriksaan biaya instalasi tegangan listrik rendah di PT PPILN Maluku Utara, Sistem yang dibuat berbasis Website dikarenakan membutuhkan efisiensi agar pimpinan dalam mengontorol laporan yang dapat dilakukan pada sistem kapan dan dimana saja

\section{Rumusan Masalah}

Berdasarkan latar belakang yang telah di uraikan maka dapat dirumuskan masalah sebagai berikut: Bagaimana merancang aplikasi pemeriksaan biaya instalasi tegangan listrik rendah berbasis web pada PT. PPILN Wilayah Maluku Utara?

\section{LANDASAN TEORI \\ Konsep dasar Sistem}

Menurut Hartono, B. (2013:10), Sistem adalah suatu himpunan dari berbagai bagian yang saling berhubungan secara terorganisasi berdasarkan fungsifungsinya, menjadi suatu kesatuan.

\section{Pengertian Informasi}

Menurut Gelinas dan Dull (2012:18) informasi didefinisikan sebagai data yang disajikan dalam bentuk yang membantu dalam aktifitas pengambilan keputusan. Informasi tersebut mempunyai nilai kepada pengambil keputusan karena mengurangi ketidak pastian dan meningkatkan pengetahuan akan area tertentu yang menjadi perhatian.

\section{Pengertian Sistem Informasi}


Menurut Sutabri (2012:46), sistem informasi adalah suatu sistem didalam suatu organisasi yang mempertemukan kebutuhan pengolahan transaksi harian yang mendukung fungsi operasi organisasi yang bersifat manajerial dengan kegiatan strategi dari suatu organisasi untuk dapat menyediakan kepada pihak luar tertentu dengan laporan-laporan yang diperlukan.

\section{Pengertian Biaya}

Menurut Mulyadi (2015:8) "Biaya adalah pengorbanan sumber ekonomis yang diukur dalam satuan uang, yang telah terjadi, sedang terjadi atau yang kemungkinan akan terjadi untuk tujuan tertentu.

\section{Pengertian Web}

Menurut Asropudin (2013), web adalah sebuah kumpulan halaman yang diawali dengan halaman muka yang berisikan informasi, iklan, serta program aplikasi.

\section{RAD (Rapid Aplication Development)}

RAD (Rapid Application Development) merupakan metode gabungan dari beberapa pendekatan terstruktur. Metode $R A D$ menggunakan metode iteratif (berulang) dalam mengembangkan sistem dimana model bekerja sistem dikonstruksikan di awal tahap pengembangan dengan tujuan menetapkan kebutuhan pengguna. Metode $R A D$ menekankan cakupan pemodelan bisnis (bussiness modelling), pemodelan data (data modelling), pemodelan proses (process modelling), pembuatan aplikasi (apzxplication generation) dan pengujian (testing). Metode ini dapat dikerjakan dalam waktu yang singkat hanya membutuhkan waktu 30-90 hari untuk menyelesaikan sistem perangkat lunak tersebut

Pengertian HTML
Menurut sutarman (2012) HTML (Hyper Text Markup Language) adalah bahas standar yang digunakan untuk pembuatan halaman web atau word wide web, dengan hypertext dan informasi lain yang akan ditampilkan pada halamn web. Dokumen hypertext bisa berisi teks, gambar, dan tipe informasi lain seperti data file, audio, dan program executeable.

\section{Pengertian CSS}

Menurut Saputra (2013) kepanjangan dari CSS adalah Cascading Style Sheet yang merupakan suatu bahasa pemrograman suatu bahasa pemrgraman web yang digunakan untuk mengendalikan dan membangun berbagai komponen dalam web sehingga tampilan web akan lebih rapi, terstruktur, dan seragam.

\section{Pengertian PHP}

Sibero (2013:49), “PHP adalah pemrograman interpreter yaitu proses penerjemahan beris kode sumber menjadi kode mesin yang dimengerti computer secara langsung pada saat baris kode dijalankan. PHP disebut sebagai pemograman Server Side Programing, hal ini dikarenakan seluruh prosesnya dijalankan pada server."

\section{Pengertian MySQL}

Menurut Sibero (2013), "MySQL atau dibaca My Sekuel adalah suatu Relational Database Management Sistem (RDBMS) yaitu aplikasi sistem yang menjalankan fungsi pengolahan data"

\section{Pengertian Flowchart}

menurut yakub (2012:37) bagan alir program (flowchart) merupakan bagan alir yang mirip dengan bagan alir sistem, yaitu untuk menggambarkan prosedur di dalam sistem" 


\section{Pengertian Data flow Diagram ( $D F D$ )}

Menurut Tata Sutabri (2012:117), Data Flow Diagram adalah suatu network yang menggambarkan suatu sistem automat atau komputerisasi, manualisasi, atau gabungan dari keduanya, yang penggambaranya disusun dalam bentuk kumpulan komponen sitem yang saling berhubungan sesuai aturan mainya.

\section{Pengertian Entity Relationship Diagram (ERD)}

$E R D$ ini merupakan model konseptual yang dapat mendeskripsikan hubungan antara file yang digunakan untuk memodelkan struktur data serta hubungan antara data (Yakub, 2012:68).

\section{METODE PENELITIAN}

1. Wawancara yang dilakukan peneliti dengan cara tatap muka langsung dan tanya jawab langsung dengan pimpinan dan bendahara pada PT PPILN Maluku Utara.

2. Observasi metode pengumpulan data yang digunakan dengan cara mengamati secara langsung tentang bagaimana proses pengelolaan laporan biaya pemeriksaan instalasi listrik di PT PPILN Maluku Utara.

3. Dokumentasi peneliti mengumpulkan dan mempelajari data/informasi yang berasal dari buku-buku dan dokumen lain terutama pada skripsi dan pada jurnal online

4. Pendekatan Analisys Sistem menggunakan Model driven secara Terstruktur, dimana setelah permasalahan diidentifikasi kemudian membuat Desain Analisa sistem yang berjalan dan diusulkan menggunakan alat bantu Flowchart pada aplikasi Microsoft Visio 2016, Model Desain yang dibuat menggunakan pendekatan Bottom Up dimana sistem identifikasi sistem dimulai dari level bawah organisasi, yaitu level operasional tempat transaksi dilakukan.

5. Pengembangan System menggunakan model Rapid Application Development (RAD) dimana melakukan pertemuan dengan user untuk mengidentifikasi tujuan dari sistem dan kebutuhan informasi untuk mencapai tujuan dan kesepakatan, setelah itu membuat desain sistem dan melakukan konfirmasi ke user apabila hasil desain sistem disetujui, maka tahap berikut melakukan coding serta implementasi dan pengujian sistem, user dapat menanggapi hasil dari pengujian sebagai evaluasi sistem

RAD 30-90 hari

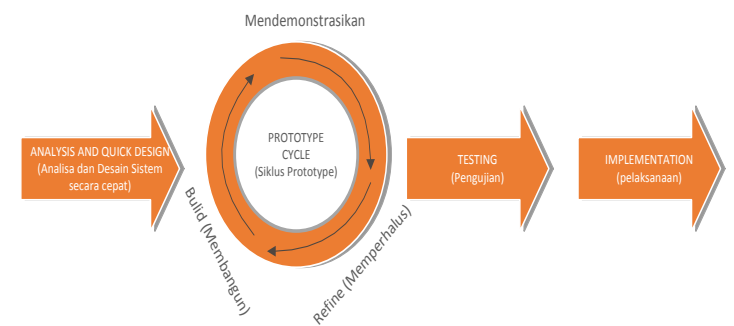

Gambar 1. Model Pengembangan RAD Sumber: A Ambarita, 2019

\section{Alat dan Bahan yang digunakan}

Adapun alat dan bahan yang digunakan dalam penelitian ini, adalah sebagai beikut :

1. Perangkat Lunak (software)

a. Sistem operasional windows 7 ultimate

b. Xampp

c. Sublime Text 3

d. Microsoft Word 2007

e. Google Chrome

f. Bahasa pemrograman $H T M L, C S S$, PHP, Java Scipt, MYSQL database

2. Perangkat Keras (Hadware)

a. Laptop Acer Aspire One 722

b. Printer Cannon IP2770 

c. Keyboard
d. Ram 2. $00 \mathrm{~GB}$
e. Hardisk $500 \mathrm{~GB}$

\section{Rancangan Alur Penilitian}

Rancangan alur penelitian merupakan alur proses penelitian yang akan dilakukan oleh peneliti dalam mengerjakan tahapan penilitian

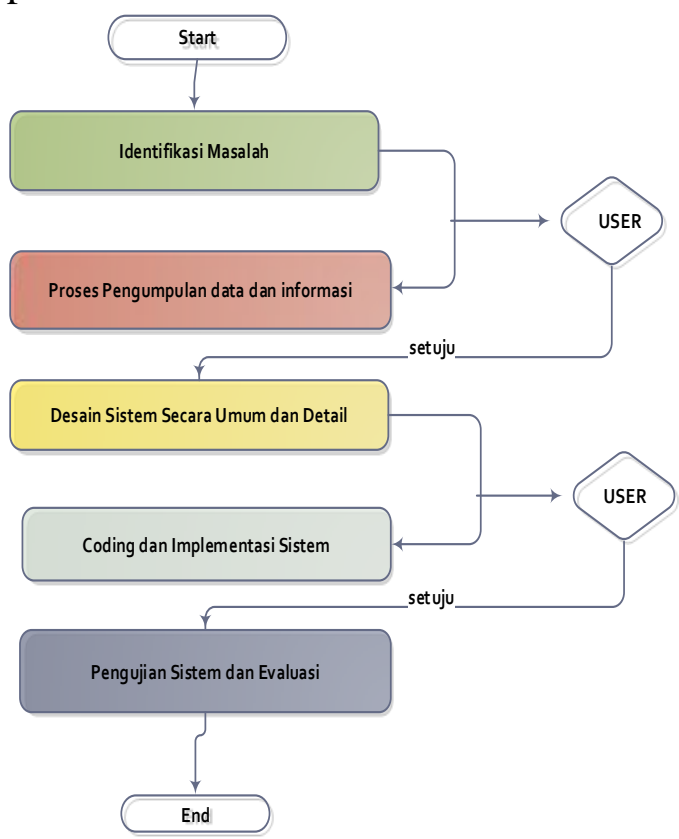

Gambar 2. Kerangka Penilitian

Sumber: A Ambarita, 2019

\section{Analisa Sistem yang Berjalan}

Analisis sistem merupakan gambaran tentang sistem yang saat ini sedang berjalan dan mempelajari sistem yang ada. Analisis sistem diperlukan untuk menggambarkan aliran informasi yang terkait, untuk mengindentifikasi dan mengevaluasi permasalahan, hambatan yang terjadi dan kebutuhan yang diharapkan sehingga dapat diusulkan perbaikan yang akan dilakukan pada sistem tersebut kemudian dibuat perancangan aplikasinya.

Analisis sistem yang sedang berjalan akan membahas mengenai prosedur, flow, diagram konteks dan data flow diagram pada sistem informasi laporan keuangan yang sedang berjalan di PT. PPILN Wilayah maluku utara ini.

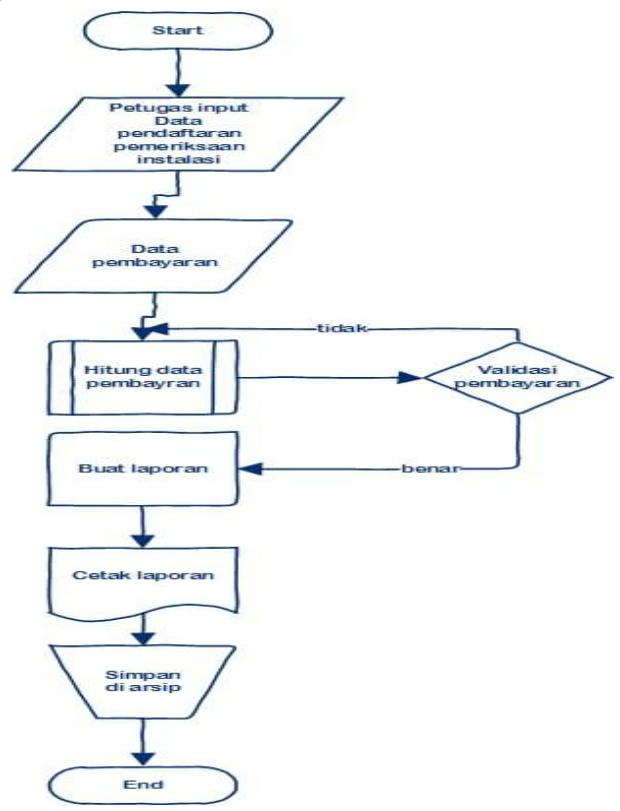

Gambar 3. System yang berjalan

\section{Rancangan System yang Diusulkan}

Berdasarkan kelemahan-kelemahan yang terdapat pada sistem yang berjalan, maka dapat diusulkan sistem yang terkomputerisasi, yakni pembuatan aplikasi web Pembayaran biaya pemeriksaan instalasi listrik pada PT. PPILN wilayah Maluku Utara. Sistem yang baru ini diharapkan dapat membantu Admin dalam melakukan transaksi lebih cepat, praktis dan efisien

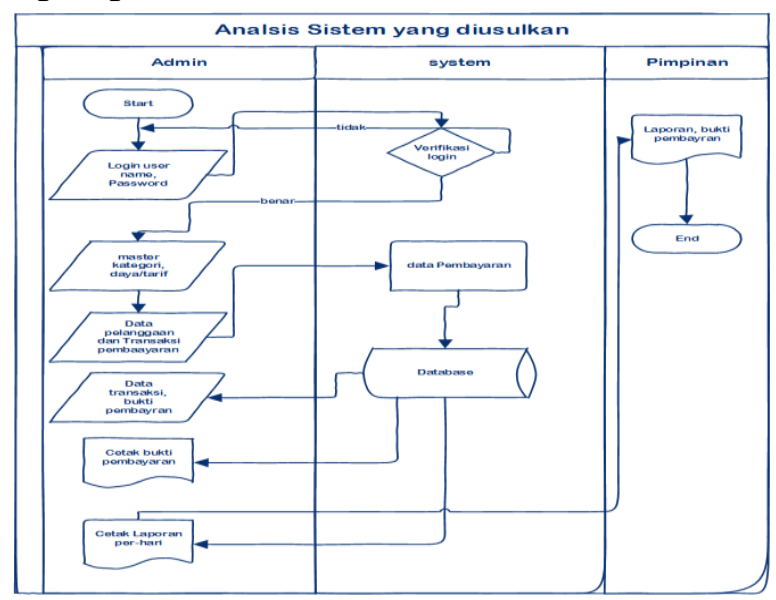

Gambar 4. Flowchart Sistem Yang Diusulkan

Kebutuhan Fungsional 
Kebutuhan fungsional adalah kebutuhan-kebutuhan yang memiliki keterkaitan langsung dengan sistem. Kebutuhan fungsional dari sistem ini adalah :

1. Kebutuhan Admin

a. Melakukan login pada sistem

b. Mengelola data kategori, daya dan biaya instalasi pada sistem

c. Mengelola data pemeriksaan instalasi pada setiap pelanggan disistem

d. Melihat rekapan laporan disistem

e. Mencetak data laporan disistem

2. Kebutuhan Pimpinan

a. Dapat melihat laporan pada sistem

b. Dapat mencetak rekapan laporan pada sistem

\section{Kebutuhan Non-Fungsional}

Kebutuhan non-fungsional adalah kebutuhan yang tidak secara langsung terkait dengan fitur tertentu di dalam system, antara lain:

1. Aplikasi ini dapat berjalan pada sistem Operasi Windows 7 ultimate 64 Bit.

2. Aplikasi dapat berjalan pada memori memori sebesar 2 GB

3. Aplikasi berjalan pada browser Mozilla dan Chrome

4. Media Server berjalan pada aplikasi Xampp versi 3.2.1. Menggunakan Databse MySQL

5. Aplikasi menggunakan menggunakan bahasa pemrograman HTML, PHP, CSS, JavaScript

\section{PERANCANGAN SISTEM}

Perancangan Tabel Database

Tabel Data Login

Tabel 1. Data Login

\begin{tabular}{|c|c|c|c|}
\hline File Name & $\begin{array}{c}\text { Data } \\
\text { Type }\end{array}$ & $\begin{array}{c}\text { File } \\
\text { Size }\end{array}$ & Description \\
\hline No & Int & 15 & Nomor \\
\hline
\end{tabular}

\begin{tabular}{|c|c|c|c|}
\hline User_Name & Varchar & 25 & Nama User \\
\hline Password & Varchar & 25 & Password \\
\hline
\end{tabular}

Tabel Biaya

Tabel 2. db Biaya

\begin{tabular}{|c|c|c|c|}
\hline File Name & $\begin{array}{c}\text { Data } \\
\text { Type }\end{array}$ & $\begin{array}{c}\text { File } \\
\text { Size }\end{array}$ & Description \\
\hline No & Int & 15 & Nomor \\
\hline Nama_daya & Varchar & 25 & Nama Daya \\
\hline biaya & Varchar & 25 & Biaya \\
\hline
\end{tabular}

Tabel Kategori

Tabel 3. db Kategori

\begin{tabular}{|c|c|c|c|}
\hline File Name & $\begin{array}{c}\text { Data } \\
\text { Type }\end{array}$ & $\begin{array}{c}\text { File } \\
\text { Size }\end{array}$ & Description \\
\hline No & Int & 15 & Nomor \\
\hline Kode_Kategori & Varchar & 25 & $\begin{array}{c}\text { Kode } \\
\text { Kategori }\end{array}$ \\
\hline Nama_Kategori & Varchar & 100 & $\begin{array}{c}\text { Nama } \\
\text { Kategori }\end{array}$ \\
\hline
\end{tabular}

Tabel Pendaftaran

Tabel 4. Pendaftaran

\begin{tabular}{|c|c|c|c|}
\hline File Name & $\begin{array}{c}\text { Data } \\
\text { Type }\end{array}$ & $\begin{array}{c}\text { File } \\
\text { Size }\end{array}$ & Description \\
\hline Id_pendaftaran & Int & 15 & $\begin{array}{c}\text { No id } \\
\text { pendaftaran }\end{array}$ \\
\hline Nama & Varchar & 50 & Nama \\
\hline Alamat & Varchar & 100 & Alamat \\
\hline Tgl_daftar & Data & 50 & $\begin{array}{c}\text { Tanggal } \\
\text { daftar }\end{array}$ \\
\hline Nama_kategori & Varchar & 50 & $\begin{array}{c}\text { Nama } \\
\text { kategori }\end{array}$ \\
\hline Nama_daya & Varchar & 50 & Nama daya \\
\hline Biaya & Varchar & 50 & Biaya \\
\hline
\end{tabular}

\section{Diagram Konteks}

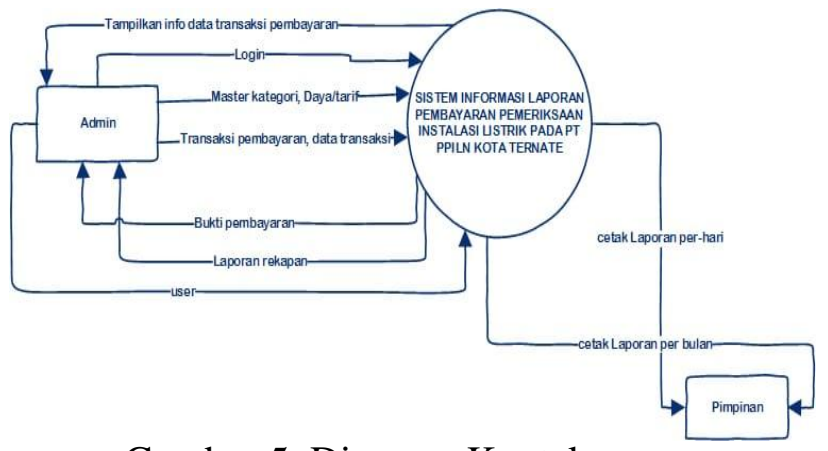

Gambar 5. Diagram Konteks 


\section{DFD Level 1}

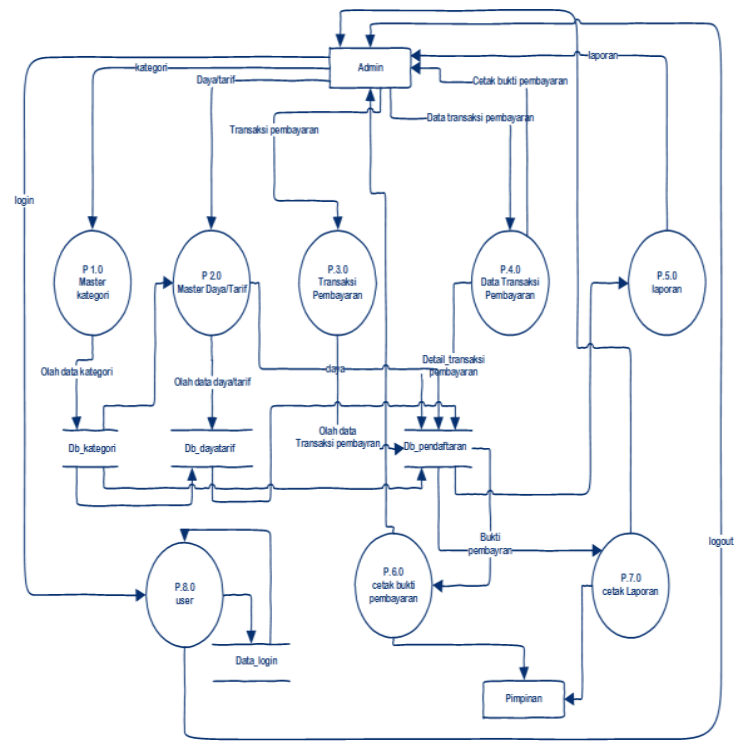

Gambar 6. Diagram Level 0

\section{Entity Relationship Diagram (ERD) Relasi Tabel}

Entity Relationship Diagram atau yang biasa disingkat ERD merupakan rancangan model database relasi antar entity dan objek, berikut merupakan hasil rancagan $E R D$ relasi tabel
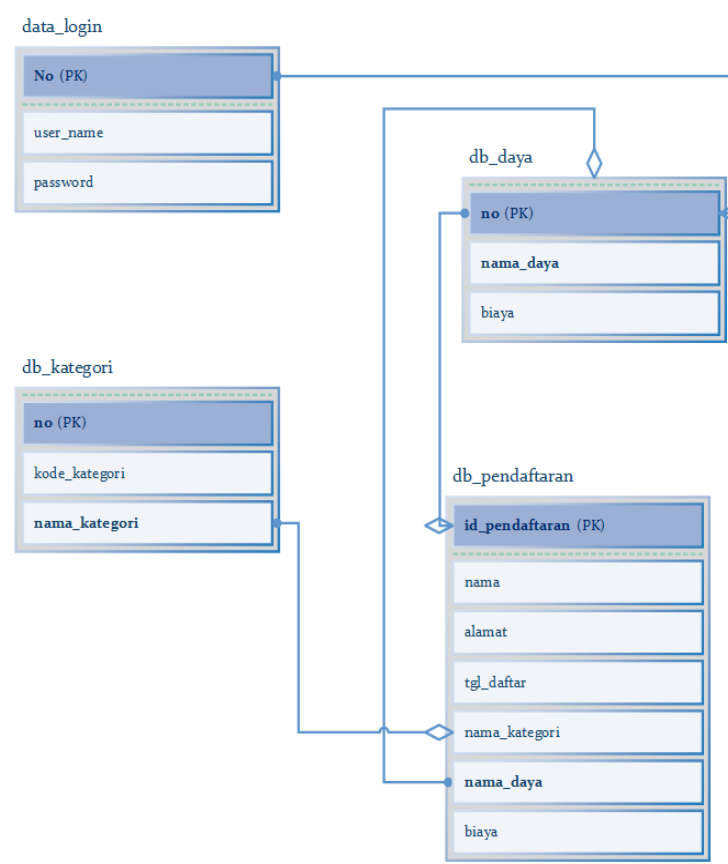

Gambar 7. Relasi Tabel

Entity Relationship Diagram (ERD) Notasi

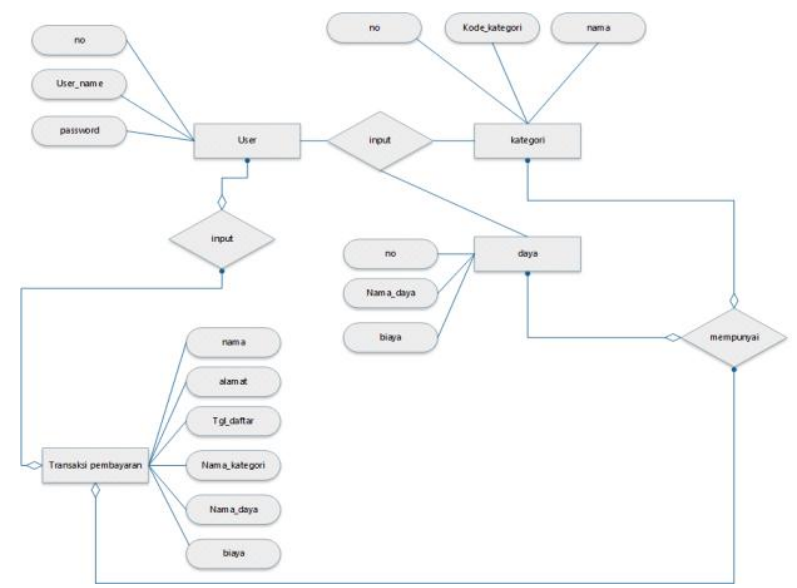

Gambar 8. ERD Notasi

\section{IMPLEMENTASI SISTEM}

Implementasi sistem merupakan hasil eksekusi dari sistem aplikasi yang dibuat. Pada bab ini akan dijelaskan bagaimana tampilan input dan output dari sistem pendukung keputusan untuk biaya pemeriksaan instalasi listrik PT. PPILN yang telah dibuat. Di dalam implemtasi sistem ini nantinya juga akan dijelaskan langkah-langka penggunaan dari tiap-tiap menu yang ada pada aplikasi pembayaran pemeriksaan instalasi listrik tersebut.

\section{Menu Utama Admin}

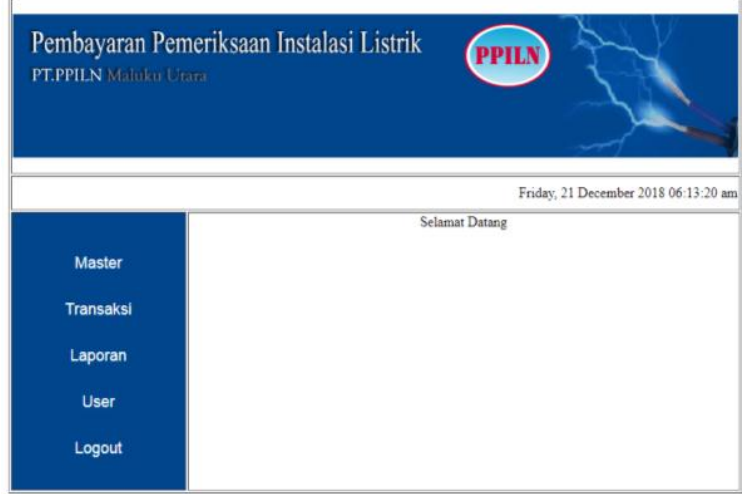

Gambar 9. Tampilan Menu utama Admin

\section{Halaman Menu Login}

Halaman login merupakan tampilan halaman saat admin akan memasukan user name dan password untuk divalidasi agar bisa masuk ke halaman berikutnya 


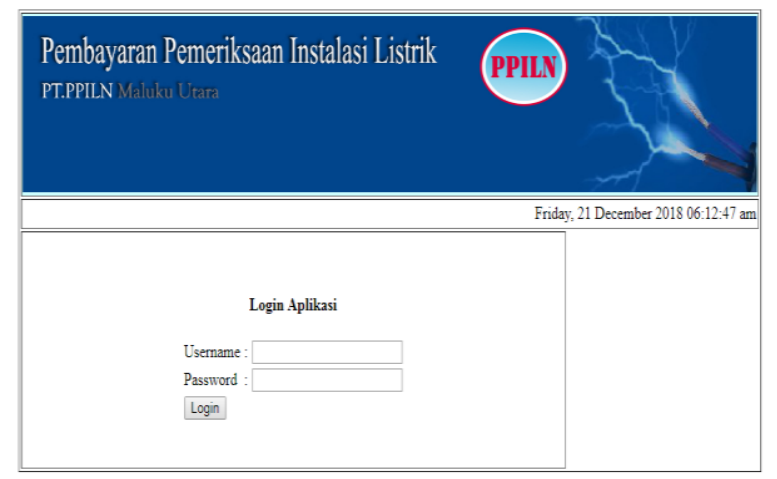

Gambar 10. Menu Login Admin

\section{Halaman Menu Master Kategori}

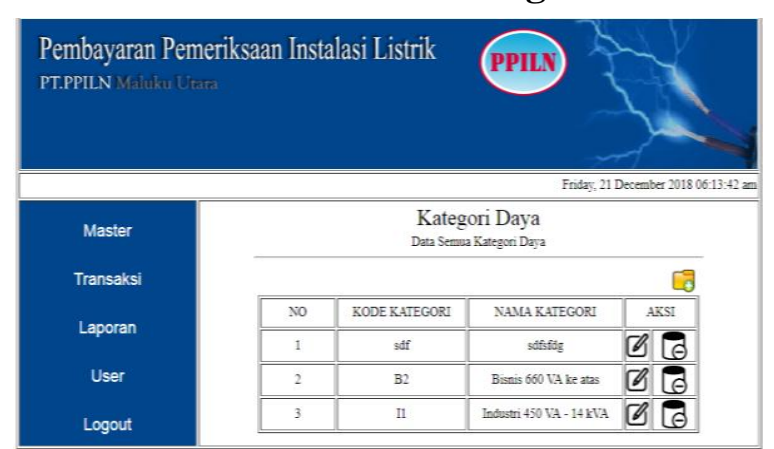

Gambar 11. Menu Master Kategori

\section{Halaman Menu Master Data}

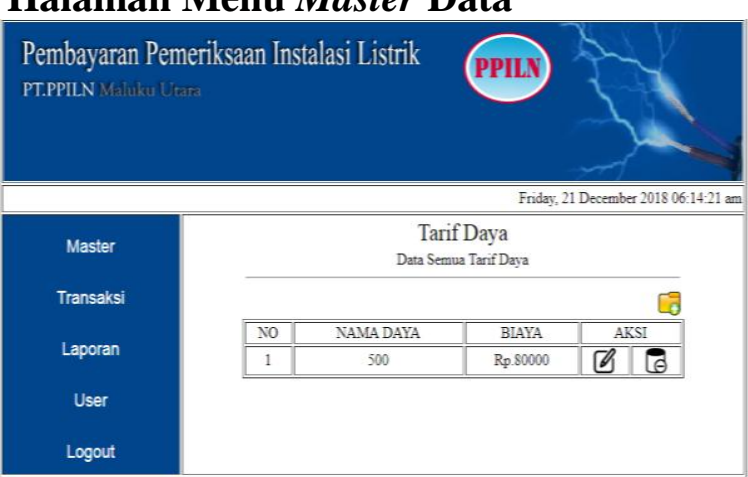

Gambar 12. Menu Master daya

\section{Halaman Menu Transaksi Pembayaran}

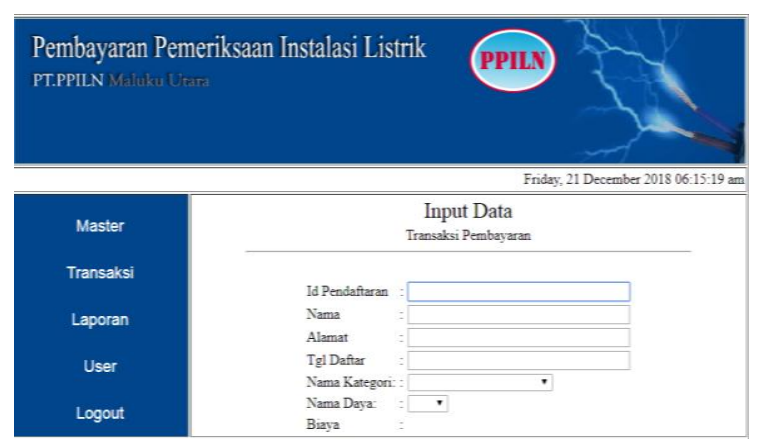

Gambar 13. Menu Transaksi Pembayaran

\section{Halaman Menu Laporan Bukti Pembayaran}

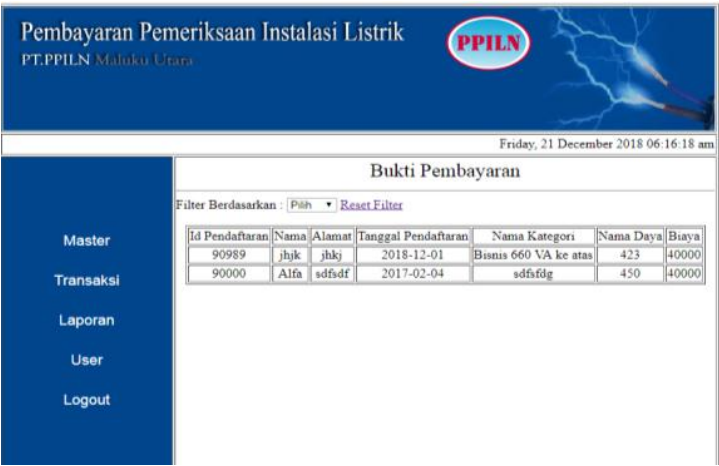

Gambar 14. Menu Master Kategori

\section{Pengujian Sistem Blackbox}

Tabel 5. Tabel Pengujian Sistem

\begin{tabular}{|c|c|c|c|c|c|c|}
\hline No & $\begin{array}{l}\text { Antar } \\
\text { Muka }\end{array}$ & $\begin{array}{l}\text { Uji } \\
\text { Coba }\end{array}$ & $\begin{array}{l}\text { Status } \\
\text { Aplikas }\end{array}$ & $\begin{array}{l}\text { Skena } \\
\text { rio } \\
\text { Pengu } \\
\text { jian }\end{array}$ & $\begin{array}{c}\text { Hasil } \\
\text { yang } \\
\text { di } \\
\text { harap } \\
\text { kan }\end{array}$ & $\begin{array}{c}\text { Hasil } \\
\text { Pengu } \\
\text { jian }\end{array}$ \\
\hline 1. & $\begin{array}{c}\text { Tampil } \\
\text { an } \\
\text { Login } \\
\text { Admin }\end{array}$ & $\begin{array}{l}\text { Mengu } \\
\text { i proses } \\
\text { login }\end{array}$ & \begin{tabular}{|l} 
Masu \\
$\mathrm{k}$ \\
menu \\
utama \\
admin
\end{tabular} & \begin{tabular}{|l|} 
Input \\
userna \\
me dan \\
passwo \\
rd dan \\
pilih \\
level
\end{tabular} & $\begin{array}{l}\text { Berha } \\
\text { sil } \\
\text { melak } \\
\text { ukan } \\
\text { valida } \\
\text { si }\end{array}$ & $\begin{array}{l}\text { Berhasil } \\
\text { masuk k } \\
\text { Menu } \\
\text { utama }\end{array}$ \\
\hline 2. & $\begin{array}{l}\text { Tampil } \\
\text { an } \\
\text { utama } \\
\text { admin }\end{array}$ & $\begin{array}{l}\text { Menguj } \\
\text { i semua } \\
\text { menu } \\
\text { yang } \\
\text { terdapa } \\
\text { t pada } \\
\text { halama } \\
n \text { web }\end{array}$ & $\begin{array}{l}\text { Tampila } \\
\text { n } \\
\text { halaman } \\
\text { web } \\
\text { sudah } \\
\text { terbuka }\end{array}$ & \begin{tabular}{|l|} 
Klik \\
menu \\
yang \\
tersedia
\end{tabular} & $\begin{array}{l}\text { Menu } \\
\text { yang } \\
\text { dipilih } \\
\text { dapat } \\
\text { memb } \\
\text { uka } \\
\text { halam } \\
\text { an }\end{array}$ & $\begin{array}{l}\text { Menu } \\
\text { yang } \\
\text { dipilih } \\
\text { dapat } \\
\text { nembuka } \\
\text { halaman }\end{array}$ \\
\hline 3. & $\begin{array}{l}\text { Tamp } \\
\text { ilan } \\
\text { menu } \\
\text { maste } \\
\text { r } \\
\text { Keteg } \\
\text { ori }\end{array}$ & $\begin{array}{l}\text { Meng } \\
\text { uji } \\
\text { untuk } \\
\text { mena } \\
\text { mbah } \\
\text { kateg } \\
\text { ori }\end{array}$ & $\begin{array}{l}\text { Masu } \\
\mathrm{k} \text { pada } \\
\text { add } \\
\text { katego } \\
\text { ri }\end{array}$ & $\begin{array}{l}\text { Masuk } \\
\text { kan } \\
\text { nama } \\
\text { dan } \\
\text { ketera } \\
\text { ngan } \\
\text { katego } \\
\text { ri }\end{array}$ & $\begin{array}{l}\text { Menu } \\
\text { yang } \\
\text { dipili } \\
\mathrm{h} \\
\text { dapat } \\
\text { mena } \\
\text { mbah } \\
\text { kateg } \\
\text { ori }\end{array}$ & $\begin{array}{l}\text { Menu } \\
\text { yang } \\
\text { dipilih } \\
\text { dapat } \\
\text { menam } \\
\text { bah } \\
\text { kategori }\end{array}$ \\
\hline 4. & $\begin{array}{l}\text { Tamp } \\
\text { ilan } \\
\text { menu }\end{array}$ & $\begin{array}{l}\text { Meng } \\
\text { uji } \\
\text { untuk }\end{array}$ & $\begin{array}{l}\text { Masu } \\
\text { k pada } \\
\text { master }\end{array}$ & $\begin{array}{l}\text { Masuk } \\
\text { an } \\
\text { daya/t }\end{array}$ & $\begin{array}{l}\text { Menu } \\
\text { yang } \\
\text { dipili }\end{array}$ & $\begin{array}{l}\text { Menu } \\
\text { yang } \\
\text { dipilih }\end{array}$ \\
\hline
\end{tabular}

Volume 4 Nomor 1 | April 2019 


\begin{tabular}{|c|c|c|c|c|c|c|}
\hline & $\begin{array}{l}\text { maste } \\
\mathrm{r} \\
\text { daya/t } \\
\text { arif }\end{array}$ & $\begin{array}{l}\text { mena } \\
\text { mbah } \\
\text { maste } \\
\mathrm{r} \\
\text { daya/t } \\
\text { arif }\end{array}$ & $\begin{array}{l}\text { daya/t } \\
\text { arif }\end{array}$ & arif & $\begin{array}{l}\mathrm{h} \\
\text { dapat } \\
\text { mena } \\
\text { mbah } \\
\text { daya/t } \\
\text { arif }\end{array}$ & $\begin{array}{l}\text { dapat } \\
\text { menam } \\
\text { bah } \\
\text { daya/tar } \\
\text { if }\end{array}$ \\
\hline 5. & $\begin{array}{l}\text { Tamp } \\
\text { ilan } \\
\text { Trans } \\
\text { aksi } \\
\text { Pemb } \\
\text { ayara } \\
\text { n }\end{array}$ & $\begin{array}{l}\text { Meng } \\
\text { uji } \\
\text { Prose } \\
\text { s } \\
\text { Trans } \\
\text { aksi } \\
\text { Peme } \\
\text { sanan }\end{array}$ & $\begin{array}{l}\text { Tampi } \\
\text { lan } \\
\text { Trans } \\
\text { aksi } \\
\text { Pemes } \\
\text { anan }\end{array}$ & 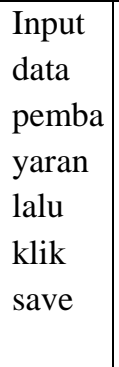 & $\begin{array}{l}\text { Berha } \\
\text { sil } \\
\text { Disim } \\
\text { pan }\end{array}$ & $\begin{array}{l}\text { Berhasil } \\
\text { disimpa } \\
\mathrm{n}\end{array}$ \\
\hline 6. & $\begin{array}{l}\text { Tamp } \\
\text { ilan } \\
\text { Lapor } \\
\text { an } \\
\text { Pemb } \\
\text { ayara } \\
\text { n }\end{array}$ & $\begin{array}{l}\text { Meng } \\
\text { uji } \\
\text { Prose } \\
\text { s } \\
\text { Input } \\
\text { Pemb } \\
\text { ayara } \\
\mathrm{n}\end{array}$ & $\begin{array}{l}\text { Tampi } \\
\text { lan } \\
\text { Hasil } \\
\text { Input } \\
\text { Pemb } \\
\text { ayaran }\end{array}$ & $\begin{array}{l}\text { Hasil } \\
\text { data } \\
\text { Pemba } \\
\text { aran } \\
\text { yang } \\
\text { akan di } \\
\text { cetak }\end{array}$ & $\begin{array}{l}\text { Berha } \\
\text { sil di } \\
\text { cetak }\end{array}$ & $\begin{array}{l}\text { Berhasil } \\
\text { di cetak }\end{array}$ \\
\hline 7. & $\begin{array}{l}\text { Tam } \\
\text { pilan } \\
\text { user }\end{array}$ & $\begin{array}{l}\text { Men } \\
\text { guji } \\
\text { pros } \\
\text { es } \\
\text { user }\end{array}$ & $\begin{array}{l}\text { Tampi } \\
\text { lkan } \\
\text { hasil } \\
\text { edit } \\
\text { dan } \\
\text { tamba } \\
\text { h user }\end{array}$ & & $\begin{array}{c}\text { Input } \\
\text { user } \\
\text { nama } \\
\text { dan } \\
\text { pass } \\
\text { word }\end{array}$ & $\begin{array}{c}\text { Mena } \\
\text { mbah } \\
\text { user }\end{array}$ \\
\hline
\end{tabular}

\section{KESIMPULAN}

Berdasarkan Implementasi dan Pengujian Sistem yang telah dilakukan, maka dapat diberikan kesimpulan pada Aplikasi Web Sistem Pemeriksaan Biaya Instalasi Tegangan Listrik Rendah Pada PT. PPILN Wilayah Maluku Utara diantaranya sebagai berikut: 1). Aplikasi ini mempermudah karyawan dalam mengelola serta proses penjumlahan data rekapan laporan secara otomatis pada sistem secara cepat tanpa harus berpindah sheet. 2). Mempermudah dalam kepada pimpinan dalam mengontrol pelaporan pada sistem yang adapat dilakukan dimana saja
Hartono, B. (2013). Sistem Informasi Manajemen Berbasis Komputer. Rineka Cipta. Jakarta.

Gelinas, J.U., Dull, Richard B., Wheeler, Patrick R. 2012. Accounting Information Systems. Cengage Learning South-Western:

Sutabri, T. ( 2012). Analisis Sistem Informasi. Andi. Yogyakarta.

Mulyadi. 2015. Akuntansi Biaya, Edisi5. Sekolah Tinggi Ilmu Manajemen YKPN. Yogyakarta:

Asropudin, P. (2013). Kamus Teknologi Informasi. Titian Ilmu. Bandung.

Sutarman, (2012). Pengantar Teknologi Informasi.. Bumi Aksara. Jakarta

Saputra, A. (2011). Trik dan Solusi Jitu Pemrograman PHP. Jakarta: IKAPI.

Sibero, A. F.K. (2013). Web Programming Power Pack. Mediakom. Yogyakarta

Sukamto, Rosa Ariani \& Shalahuddin, M. 2014. Rekayasa Perangkat Lunak. Bandung: Informatika Bandung.

Yakub (2012). Pengantar Sistem Informasi. Graha Ilmu. Yogyakarta

Yuanita dan Sukadi dengan, Sistem Informasi Administrasi Pembayaran Iuran Bulanan (SPP) Dan Dana Sumbangan Pendidikan (DSP) Siswa Taman Kanak-Kanak Negeri Pembina Kecamatan Pringkuku, Journal Speed - Sentra Penilitian Engineering \& edukasi, Vol No 4 Tahun 2010, pp 42-47, ISSN: 20880154

Sandy Kosasi, I Dewa Ayu Eka Yuliani, Penerapan Rapid Application Development Pada Sistem Penjualan Sepeda Online, Jurnal SIMETRIS, Vol 6 No 1 April 2015, ISSN: 22524983

\section{DAFTAR PUSTAKA}

